\title{
Effect of Plant Growth Regulators and Micronutrients on Vegetative Growth and Fruit Yield of Strawberry (Fragaria X Ananassa Duch.) cv. Chandler
}

\author{
Mahendra Bairwa*, V. M. Prasad and Vijay Bahadur
}

Department of Horticulture, Naini Agricultural Institute, Sam Higginbottom University of Agriculture, Technology and Sciences, Prayagraj(U.P.)-211007, India

*Corresponding author

K e y w o r d s
Strawberry,
Vegetative growth,
$\begin{aligned} & \text { Fruit yield, Plant } \\ & \text { growth regulators } \\ & \text { and micronutrients }\end{aligned}$
Article Info
$\begin{aligned} & \text { Accepted: } \\ & 18 \text { August } 2020 \\ & \text { Available Online: } \\ & \text { 10 September } 2020\end{aligned}$

\section{A B S T R A C T}

An investigation entitled "Effect of Plant Growth Regulators and Micronutrients on Vegetative Growth and fruit yield of Strawberry (Fragaria X Ananassa Duch.) cv. Chandler" was carried out at the Central Research Farm, Department of Horticulture, Sam Higginbottom University of Agriculture, Technology \& Science, Prayagraj, (U.P.) 211007 during the year 2015-16 and 2016-2017. The experiment was consisting of Chandler variety of Strawberry with each comprising of nineteen treatments replicated thrice. Source of variables were NAA (20ppm); GA 3 (75 ppm); BA (benzyl adenine) (20 ppm); Salicylic acid (50 ppm); Boric acid (0.4\%); Zinc sulphate $(0.4 \%)$ and combination of them with control treatment taken as nineteen treatments. The experiment was laid out in randomized block design by randomizing treatments in each replication. As far as the vegetative growth and fruit yield is concerned, application of different treatment of plant growth regulators and micronutrient significantly enhanced the Plant height $(\mathrm{cm}$.), Number of leaves per plant, Petiole length $(\mathrm{cm})$, Plant spread $(\mathrm{cm})$, Yield per plant $(\mathrm{g})$, Yield per plot (Kg.) and Yield per hectare (t) at all successive stages. Maximum Plant height (15.01 and $15.43 \mathrm{~cm})$, Number of leaves per plant (20.55 and 21.40), Petiole length $(22.56 \mathrm{~cm}$ and $24.74 \mathrm{~cm})$, Plant spread $(28.71 \mathrm{~cm}$ and $29.90 \mathrm{~cm})$, Fruit yield per plant $(\mathrm{g})(225.23 \mathrm{~g}$ and $234.80 \mathrm{~g})$, Yield per plot (Kg.) (1.13 and $1.17 \mathrm{Kg}$ ) and Yield per hectare (12.84 and 13.38 t) were recorded in successive year with $\mathrm{T}_{17}\left(\mathrm{GA}_{3} 75 \mathrm{ppm}+\right.$ Zinc sulphate $0.4 \%$ + Boric acid $0.4 \%$ ) and minimum growth and fruit yield were observed in $\mathrm{T}_{1}$.

\section{Introduction}

Strawberry (Fragaria $\mathrm{x}$ ananassa Duch.) is a short-lived (3-5 yrs.), perennial, vigorous, stoloniferous herb growing to $10-20 \mathrm{~cm}$ height with a spread of about $0.3-1.0 \mathrm{~m}$. The United States is the world's largest producer of strawberries accounting for about 30 percent of the world strawberry production (Morgan, 2012). In India, Haryana is the largest 
producer of strawberry with 2.01 million tonnes production (NHB, 2017-18). It is a minor fruit of temperate regions, due to advent of day neutral cultivars, it is being cultivated profitably even in tropical and subtropical regions. Its main center of cultivation is Nainital and Dehradun in Uttrakhand, Mahabaleshwar (Maharashtra), Kashmir Valley, Bangalore and Kalimpong (West Bengal). In recent years, strawberry is being cultivated successfully in plains of Maharashtra (around Pune, Nashik and Sangali towns), Haryana and Uttar Pradesh. The wide variation in climates within these regions and the wide adaptation of the strawberry plant permit harvesting and marketing, the fruit during greater part of the year. The temperature and day-length (photoperiodism) have the considerable effect on growth and yield of the strawberry probably through the control of the production of plant hormones. An average growing temperature of $15^{\circ} \mathrm{C}$ has been reported ideal for most of the strawberry cultivars and species. However, they grow well at a temperature range between $20^{\circ} \mathrm{C}$ and $26^{\circ} \mathrm{C}$. It has been observed that high growth rates in strawberries are maintained at day temperatures of $22-23^{\circ} \mathrm{C}$.

Strawberry is amongst the top ten fruit crops which give quicker and very high returns per unit area on to the capital investment made. The fruits of strawberry become ready for harvesting within six months of planting. A single plant of strawberry produces varying yield potential of about $500 \mathrm{~g}$ fruits per plant and per hectare average yield is about 5 tonnes/ha. It indicates that there is a scope of harvesting more yield from its cultivation. Yield is dependent upon many variables, it may be plant ideotype, cultivar, environment and care and management etc. There are many factors which influence plant health. $\mathrm{PGR}_{\mathrm{S}}$ and micronutrients are such type of input factors. Plant Growth Regulators
$\left(\mathrm{PGR}_{\mathrm{S}}\right)$ have proven their role in augmenting yield and growth in many fruits. PGR are either synthetic or natural compounds or that modify plant physiological processes at very minute concentrations. Use of $\mathrm{GA}_{3}$ in strawberry has been reported in increasing yield and quality of fruit, helps in cell elongation and cell enlargement, increase vegetative growth and minimizes time of maturity. Application of NAA delays ripening and increases anthocyanin accumulation of strawberry fruits. It increases duration of growth and improves yield of fruits. Foliar application of salicylic acid and calcium gives better improvement in yield and its component and chemical properties of strawberry. Mean comparisons indicated yield, and quality of strawberry plants was improved in low salicylic acid and calcium chloride concentration Kazemi (2014). BA as a plant growth regulator is used for different purposes in fruit production. It influences fruit size and weight by increasing the number of cells per fruit through the stimulation of cell division.

Micronutrients, forming constituent part of plant are considered essential for the growth of plants. Proper supply of these nutrients is sure to yield positive effect on crop production. Foliar application of different micronutrients at proper stage helps in improving fruit yield and physiochemical characteristics of strawberry. It also helps in correcting micronutrients deficiency. Zinc $(\mathrm{Zn})$ is an essential micro element for plants. It is involved in many enzymatic reactions. For growth and development of plant zinc is necessary (Shukla et al., 2009).

Growth of the receptacle is controlled primarily by auxin, which is synthesized in achenes, therefore $\mathrm{ZnSO}_{4}$ is applied to increase fruit number, size and quality. The above explanation clearly highlights the affectivity of $\mathrm{PGR}_{\mathrm{S}}$ and micronutrients on 
vegetative growth, and fruit yield. Hence, it is being attempted to quantify their effect on strawberry culture.

\section{Materials and Methods}

The experiment entitled "Effect of Plant Growth Regulators and Micronutrients on Vegetative Growth and fruit yield of Strawberry (Fragaria X Ananassa Duch.) cv. Chandler" was carried out as a part of investigation. All facilities to carry out the experiment were available at the Department of Horticulture, Naini Agricultural Institute, Sam Higginbottom University of Agriculture, Technology and Sciences, Prayagraj, during the year 2015-2016 and 2016-17. Allahabad district is situated in the river basin of the Ganga and Yamuna and situated at $25^{\circ} .57^{\prime} \mathrm{N}$ latitude $81^{0} .5^{\prime}$ E- longitude with an altitude of $98 \mathrm{~m}$ above the mean sea level. The soil of the experimental area is sandy loam in texture with soil reaction in almost neutral range $(\mathrm{pH}$ 7.2) organic carbon $(0.51 \%)$ is low, nitrogen $\left(225 \mathrm{~kg} \mathrm{ha}^{-1}\right)$ and potassium $\left(87.00 \mathrm{~kg} \mathrm{ha}^{-1}\right)$ is available in medium but phosphorus $(21.50$ $\mathrm{kg} \mathrm{ha}^{-1}$ ) is low. Annual rainfall is $1100 \mathrm{~mm}$ precipitating mostly in between middle of July to end of September - January is the coldest month when mercury may drop down to an average minimum of $5^{0}$ on the other hand May - June are the hottest month recording average high temperature above $46^{0}$ C.

The Strawberry crop with Chandler variety was grown in Randomized Block Design with 19 treatments and each replicated thrice. Treatment details were $\mathrm{T}_{1}$ (Control), $\mathrm{T}_{2}$ NAA (20ppm), $\mathrm{T}_{3} \mathrm{GA}_{3}$ (75ppm), $\mathrm{T}_{4}$ Salicylic acid (50ppm), $\mathrm{T}_{5}$ BA (benzyl adenine, 20ppm), $\mathrm{T}_{6}$ Zinc sulphate $(0.4 \%), \mathrm{T}_{7}$ Boric acid $(0.4 \%)$, $\mathrm{T}_{8}$ NAA $(20 \mathrm{ppm})+$ Zinc sulphate $(0.4 \%), \mathrm{T}_{9}$ NAA $(20 \mathrm{ppm})+$ Boric acid $(0.4 \%), \mathrm{T}_{10} \mathrm{GA}_{3}$ $(75 \mathrm{ppm})+$ Zinc sulphate $(0.4 \%), \mathrm{T}_{11} \mathrm{GA}_{3}$ $(75 \mathrm{ppm})+$ Boric acid $(0.4 \%), \mathrm{T}_{12}$ Salicylic acid $(50 \mathrm{ppm})+$ Zinc sulphate $(0.4 \%), \mathrm{T}_{13}$ Salicylic acid (50ppm) + Boric acid $(0.4 \%)$, $\mathrm{T}_{14}$ BA (benzyl adenine, 20ppm) + Zinc sulphate $(0.4 \%), \mathrm{T}_{15}$ BA (benzyl adenine, $20 \mathrm{ppm})+$ Boric acid $(0.4 \%), \mathrm{T}_{16}$ NAA $(20 \mathrm{ppm})+$ Zinc sulphate $(0.4 \%)+$ Boric acid $(0.4 \%), \mathrm{T}_{17} \mathrm{GA}_{3}(75 \mathrm{ppm})+$ Zinc sulphate $(0.4 \%)+$ Boric acid $(0.4 \%), \mathrm{T}_{18}$ Salicylic acid $(50 \mathrm{ppm})+$ Zinc sulphate $(0.4 \%)+$ Boric acid (0.4\%) and $\mathrm{T}_{19} \mathrm{BA}$ (benzyl adenine, 20ppm) + Zinc sulphate $(0.4 \%)+$ Boric acid $(0.4 \%)$. Each plot comprised of $1 \mathrm{~m}^{2}$ with a spacing of $45 \mathrm{~cm}$ row to row and $30 \mathrm{~cm}$ plant to plant. Each treatment carrying 6 plants per $\mathrm{m}^{2}$. The observations were recorded on vegetative growth and yield parameters of strawberry as Plant height $(\mathrm{cm}$.$) , Number of leaves per$ plant, Petiole length $(\mathrm{cm})$, Plant spread $(\mathrm{cm})$, Yield per plant (g), Yield per plot (Kg.) and Yield per hectare $(\mathrm{t})$ at all successive stages. The data were collected from five randomly selected plants of each treatment and subjected to statistical analyses as per methodology suggested by Fisher and Yates (1938).

\section{Results and Discussion}

The findings of the present experiment entitled "effect of plant growth regulators and micronutrients on vegetative growth and fruit yield of Strawberry (Fragaria $X$ Ananassa Duch.) cv. Chandler" is briefly discussed and presented in table 1 and 2. This study was under taken to examine the effect of plant growth regulators and micronutrient on vegetative growth and yield of strawberry.

In terms of vegetative parameters, it was found that Plant height, plant spread, number of leaves and Petiole length were significantly increased during the both year by different treatments of plant growth regulators and micronutrient at all successive stage of growth. 
Table.1 Effect of PGRs and micronutriensts on vegetative growth parameters of Strawberry cv. Chandler

\begin{tabular}{|c|c|c|c|c|c|c|c|c|c|c|c|c|}
\hline \multirow[t]{2}{*}{ Treatment } & \multicolumn{3}{|c|}{ Plant height 120 days } & \multicolumn{3}{|c|}{$\begin{array}{c}\text { Number of leaves per plant } \\
120 \text { days }\end{array}$} & \multicolumn{3}{|c|}{ Petiole length 120 days } & \multicolumn{3}{|c|}{ Plant spread 120 days } \\
\hline & $\begin{array}{l}2015- \\
16\end{array}$ & $\begin{array}{c}2015- \\
16\end{array}$ & Pooled & $\begin{array}{c}2015- \\
16\end{array}$ & $\begin{array}{c}2016- \\
17\end{array}$ & Pooled & $\begin{array}{c}2015- \\
16\end{array}$ & $\begin{array}{c}2016- \\
17\end{array}$ & Pooled & $\begin{array}{c}2015- \\
16\end{array}$ & $\begin{array}{c}2016- \\
17\end{array}$ & Pooled \\
\hline T1 & 9.39 & 9.64 & 9.52 & 12.22 & 12.72 & 12.47 & 7.67 & 8.4 & 8.04 & 18.01 & 19.12 & 18.57 \\
\hline $\mathbf{T} 2$ & 11.17 & 11.48 & 11.33 & 15.12 & 15.74 & 15.43 & 14.04 & 15.39 & 14.71 & 24.81 & 26.33 & 25.57 \\
\hline T3 & 12.3 & 12.64 & 12.47 & 16.09 & 16.75 & 16.42 & 16.32 & 17.89 & 17.1 & 22.8 & 24.23 & 23.52 \\
\hline T4 & 10.57 & 10.85 & 10.71 & 14.82 & 15.43 & 15.13 & 11.76 & 12.89 & 12.33 & 24.5 & 26 & 25.25 \\
\hline T5 & 9.42 & 9.67 & 9.55 & 14.36 & 14.95 & 14.65 & 11.95 & 13.1 & 12.52 & 23.91 & 25.38 & 24.65 \\
\hline T6 & 10.11 & 10.38 & 10.25 & 15.71 & 16.35 & 16.03 & 12.4 & 13.59 & 12.99 & 21.94 & 23.28 & 22.61 \\
\hline T7 & 9.72 & 9.98 & 9.85 & 15.34 & 15.97 & 15.66 & 13.55 & 14.86 & 14.21 & 21.2 & 22.5 & 21.85 \\
\hline T8 & 13.45 & 13.83 & 13.64 & 16.65 & 17.34 & 17.00 & 15.36 & 16.84 & 16.1 & 23.76 & 25.21 & 24.48 \\
\hline T9 & 12.64 & 13.01 & 12.83 & 16.59 & 17.27 & 16.93 & 13.12 & 14.38 & 13.75 & 21.47 & 22.78 & 22.13 \\
\hline T10 & 14.88 & 14.3 & 14.59 & 19.27 & 20.06 & 19.66 & 21.32 & 23.37 & 22.35 & 28.17 & 29.34 & 28.75 \\
\hline T11 & 13.17 & 13.55 & 13.36 & 18.51 & 19.28 & 18.89 & 19 & 20.83 & 19.92 & 27.32 & 29 & 28.16 \\
\hline T12 & 10.14 & 10.64 & 10.39 & 12.34 & 12.84 & 12.59 & 11.5 & 12.61 & 12.05 & 21.21 & 22.51 & 21.86 \\
\hline T13 & 10.91 & 11.22 & 11.07 & 13.3 & 13.84 & 13.57 & 15.71 & 17.22 & 16.46 & 22.78 & 24.18 & 23.48 \\
\hline T14 & 11.7 & 12.05 & 11.88 & 14.73 & 15.34 & 15.04 & 12.77 & 14 & 13.38 & 21.13 & 22.43 & 21.78 \\
\hline T15 & 12.62 & 12.96 & 12.79 & 14.4 & 14.99 & 14.7 & 13.25 & 14.53 & 13.89 & 20.49 & 21.75 & 21.12 \\
\hline T16 & 13.71 & 14.1 & 13.91 & 17.65 & 18.38 & 18.02 & 18.11 & 19.85 & 18.98 & 27.35 & 29.02 & 28.18 \\
\hline T17 & 15.01 & 15.43 & 15.22 & 20.55 & 21.4 & 20.97 & 22.56 & 24.74 & 23.65 & 28.71 & 29.9 & 29.31 \\
\hline T18 & 11.49 & 11.82 & 11.66 & 13.88 & 14.46 & 14.17 & 18.37 & 20.14 & 19.25 & 21.74 & 23.07 & 22.4 \\
\hline T19 & 12.69 & 13.06 & 12.88 & 15.2 & 15.83 & 15.52 & 12.98 & 14.23 & 13.61 & 23.1 & 24.51 & 23.8 \\
\hline CD value & 1.15 & 1.18 & 1.17 & 0.36 & 0.39 & 0.35 & 0.57 & 1.15 & 0.62 & 1.38 & 0.90 & 0.93 \\
\hline S.Ed ( $( \pm)$ & 0.57 & 0.58 & 0.58 & 0.18 & 0.19 & 0.17 & 0.28 & 0.57 & 0.31 & 0.68 & 0.44 & 0.46 \\
\hline
\end{tabular}


Table.2 Effect of PGRs and micronutriensts on fruit yield parameters of Strawberry cv. Chandler

\begin{tabular}{|c|c|c|c|c|c|c|c|c|c|}
\hline \multirow[t]{2}{*}{ Treatment } & \multicolumn{3}{|c|}{ Fruit yield per plant } & \multicolumn{3}{|c|}{ Fruits Yield per plot } & \multicolumn{3}{|c|}{ Yield per hectare } \\
\hline & 2015-2016 & 2016-2017 & Pooled & 2015-2016 & 2016-2017 & Pooled & 2015-2016 & 2016-2017 & Pooled \\
\hline T1 & 102.3 & 106.65 & 104.47 & 0.51 & 0.53 & 0.52 & 5.83 & 6.08 & 5.96 \\
\hline $\mathbf{T 2}$ & 169.75 & 176.96 & 173.36 & 0.85 & 0.88 & 0.87 & 9.68 & 10.09 & 9.88 \\
\hline T3 & 190.77 & 198.88 & 194.82 & 0.95 & 0.99 & 0.97 & 10.87 & 11.34 & 11.1 \\
\hline T4 & 163.47 & 170.42 & 166.94 & 0.82 & 0.85 & 0.83 & 9.32 & 9.71 & 9.52 \\
\hline T5 & 155.26 & 161.86 & 158.56 & 0.78 & 0.81 & 0.79 & 8.85 & 9.23 & 9.04 \\
\hline T6 & 178.45 & 186.03 & 182.24 & 0.89 & 0.93 & 0.91 & 10.17 & 10.6 & 10.39 \\
\hline $\mathbf{T 7}$ & 175.28 & 183.06 & 179.17 & 0.88 & 0.91 & 0.9 & 9.99 & 10.42 & 10.2 \\
\hline T8 & 204.23 & 212.91 & 208.57 & 1.02 & 1.06 & 1.04 & 11.64 & 12.14 & 11.89 \\
\hline T9 & 195.23 & 203.53 & 199.38 & 0.98 & 1.02 & 1 & 11.13 & 11.6 & 11.36 \\
\hline T10 & 218.26 & 227.54 & 222.9 & 1.09 & 1.14 & 1.11 & 12.44 & 12.97 & 12.71 \\
\hline T11 & 215.12 & 224.26 & 219.69 & 1.08 & 1.12 & 1.1 & 12.26 & 12.78 & 12.52 \\
\hline T12 & 165.01 & 172.02 & 168.52 & 0.83 & 0.86 & 0.84 & 9.41 & 9.81 & 9.61 \\
\hline T13 & 178.12 & 185.69 & 181.91 & 0.89 & 0.93 & 0.91 & 10.15 & 10.58 & 10.37 \\
\hline T14 & 186.96 & 194.91 & 190.93 & 0.93 & 0.97 & 0.95 & 10.66 & 11.11 & 10.88 \\
\hline T15 & 175.24 & 182.69 & 178.96 & 0.88 & 0.91 & 0.89 & 9.99 & 10.41 & 10.2 \\
\hline T16 & 210.33 & 219.27 & 214.8 & 1.05 & 1.1 & 1.07 & 11.99 & 12.5 & 12.24 \\
\hline T17 & 225.23 & 234.8 & 230.02 & 1.13 & 1.17 & 1.15 & 12.84 & 13.38 & 13.11 \\
\hline T18 & 184.45 & 192.29 & 188.37 & 0.92 & 0.96 & 0.94 & 10.51 & 10.96 & 10.74 \\
\hline T19 & 190.12 & 198.2 & 194.16 & 0.95 & 0.99 & 0.97 & 10.84 & 11.3 & 11.07 \\
\hline CD value & 1.45 & 1.52 & 1.01 & 0.07 & 0.06 & 0.05 & 0.83 & 0.66 & 0.56 \\
\hline S.Ed ( $( \pm)$ & 0.73 & 0.76 & 0.51 & 0.04 & 0.03 & 0.02 & 0.41 & 0.33 & 0.28 \\
\hline
\end{tabular}


The maximum values for Plant height $(15.01 \mathrm{~cm} 15.43 \mathrm{~cm}$ and $15.22 \mathrm{~cm}$ in $2015-16$, 2016-17 and pooled respectively) with close conformity of Singh and Tripathi (2010); Maximum plant spread $(28.71 \mathrm{~cm}, 29.90 \mathrm{~cm}$ and $29.31 \mathrm{~cm}$ in $2015-16,2016-17$ and pooled respectively) similar to Muneshwar et al., (2012); number of leaves $(20.55,21.40$, and 20.97 in 2015-16, 2016-17 and pooled respectively) closely associated with Vishal et al., (2016), Eraslan et al., (2007) and Suvalaxmi et al., (2016) and maximum petiole length $(22.56 \mathrm{~cm}, 24.74 \mathrm{~cm}$ and $23.65 \mathrm{~cm}$ in 2015-16, 2016-17 and pooled respectively) closely related with results of Saima et al., (2014) and Kumar et al., (2011), were recorded in treatment $\mathrm{T}_{17}\left(\mathrm{GA}_{3} 75 \mathrm{ppm}\right.$ + Zinc sulphate $0.4 \%+$ Boric acid $0.4 \%$ ), whereas minimum results for Plant height $(9.39 \mathrm{~cm}, 9.64 \mathrm{~cm}$ and $9.52 \mathrm{~cm}$ in $2015-16$, 2016-17 and pooled respectively), plant spread $(18.01 \mathrm{~cm}, 19.12 \mathrm{~cm}$ and $18.57 \mathrm{~cm}$ in 2015-16, 2016-17 and pooled respectively), number of leaves $(12.22,12.72$ and 12.47 in 2015-16, 2016-17 and pooled respectively) and Petiole length $(7.67 \mathrm{~cm}, 8.40 \mathrm{~cm}$ and $8.04 \mathrm{~cm}$ in $2015-16$ and $2016-17$ and pooled respectively) were observed with $T_{1}$ (Recommended dose of nutrients of chemical fertilizers), and these findings are in close conformity by Roshni et al., (2018), Qureshi et al., (2013); O' Neil and Ross (2002) and Rademabher (2000).

In the yield parameters, yield per plant $(\mathrm{g})$, yield per plot (Kg.) and fruit yield per hectare (t) at different intervals (5 days after first picking) of picking fruits were significantly increased by different treatments of plant growth regulators and micronutrient at all successive stage of yield attributes during the both year of experiment. Where maximum fruit yield per plant $(\mathrm{g})(225.23 \mathrm{~g}),(234.8 \mathrm{~g})$ and $(230.02 \mathrm{~g})$ in 2015-16, 2016-17 and pooled respectively, maximum yield per plot (Kg.) $(1.13 \mathrm{~kg}),(1.17 \mathrm{~kg})$ and $(1.15 \mathrm{~kg})$ in 2015-16, 2016-17 and pooled respectively and maximum yield per hectare $(12.84 \mathrm{t}, 13.3 \mathrm{t}$ and 13.11t in 2015-16, 2016-17 and pooled respectively) were recorded in both successive year in $\mathrm{T}_{17}\left(\mathrm{GA}_{3} 75 \mathrm{ppm}+\right.$ Zinc sulphate $0.4 \%+$ Boric acid $0.4 \%$ ), while minimum Fruit yield per plant $(\mathrm{g})(102.3 \mathrm{~g})$, $(106.65 \mathrm{~g})$ and $(104.47 \mathrm{~g})$ at different intervals of picking in 2015-16, 2016-17 and pooled respectively, Yield per plot (Kg.) 0.51 $\mathrm{Kg}),(0.53 \mathrm{Kg})$ and $(0.52 \mathrm{Kg})$ in $2015-16$, 2016-17 and pooled respectively and Yield per hectare (5.83 tonne), (6.08 tonne) and (5.96 tonne) in 2015-16, 2016-17 and pooled respectively, were recorded in $\mathrm{T}_{1}$. Roshni et al., (2018), Yadav et al., (2017) and Rafeii and Pakkish (2014) also reported the similar response in terms of yield with the application of plant growth regulators and micronutrient and stated that it is due to the better physiological and metabolic activity of growth hormones and micronutrient combinations in strawberry plants.

It is concluded, on the basis of present investigation in both successive year 2015-16 and 2016-17, it is concluded that the treatment $\mathrm{T}_{17}\left(\mathrm{GA}_{3} 75 \mathrm{ppm}+\right.$ Zinc sulphate $0.4 \%+$ Boric acid $0.4 \%$ ) was found best in terms of vegetative growth and yield characters of strawberry. So application of this PGR and Micronutrient combination can be recommended to growers after few more conjunctive trials.

\section{References}

Eraslan, F., Inal, A., Gunes, A. and Alpaslan, M. (2007). Impact of exogenous salicylic acid on the growth, antioxidant activity and physiology of carrot plants subjected to combined salinity and boron toxicity. Scientia Horticulturae. 113: 120-128.

Fisher, R.A. and Yates, F. (1938) Statistical Tables for Biological, Agricultural, and Medical Research. Oliver and Boyd, London, 20, Example 12.

Kazemi, M. (2014). Influence of foliar application of iron, calcium and zinc sulphate on 
vegetative growth and reproductive characteristics of strawberry cv. Pajaro. Trakia Journal of Sciences, 12(1): 21-26.

Kumar, R., Saravanan, S., Bakshi, P. and Srivastava, J.N. (2011). Influence of plant growth regulators on growth, yield and quality of strawberry cv. Sweet Charlie. Progessive Horticulture, 43(2): 264-267.

Morgan, K. L. (2012). Commodity strawberry profile. Mississippi University. http://www.agmrc.org/commoditiesproducts/f ruits/strawberries/commodity-strawberryprofile (20.10.2013).

Muneshwar Prasad, Manorama Minz, Rajesh Kumar and Bikash Das (2012). Effect of mulcidng and PGRs on growth, yield and economics of strawberry (Fragaria annanassa Ducb.) CV. Douglas. J fnteracad, $16(1) ; 44-55$.

NHB, (2017-18). National Horticulture Board, Gurgaon, Haryana.

O' Neil., D.P. and Ross., J.J. (2002). Regulation of gibberalin pathway in pea. Plant physiol, 130: 1974-1982.

Qureshi, K.M., Chughtai, S., Qureshi, U.S. and Abbasi, N.A. (2013). Impact of exogenous application of salt and growth regulators on growth and yield of strawberry. Pak. J. Bot., 45(4): 1179-1185.

Rademabher, W. (2000). Growth retardants: Effect of gibberellins biosynthesis and other biosynthesis and other metabolic pathway. Annual review of plant physiology and plant molecular biology. 51: 501-531.

Rafeii, S. and Pakkish, Z. (2014). Effect of boric acid spray on growth and development of 'Camarosa' strawberry (Fragaria $x$ ananassa Duch.). International Journal of Advance Biological and Biomedical Research, 2(4): 1060-1063.

Roshni Aradhana Ekka, Ravindra Kumar Singh, S
Saravanan and Saurabh Kasera (2018). Foliar application of micronutrients influenced vegetative growth, yield and quality traits of strawberry (Fragaria x ananassa Duch.) cv. Chandler. J. of Pharmacognosy and Phytochemistry, SP1: 2030-2032.

Saima, Z., Sharma, A., Umar, I. and Wali, V.K. (2014). Effect of plant bio-regulators on vegetative growth, yield and quality of strawberry cv. Chandler. African Journal of Agricultural Research, 9(22): 1694-1699.

Shukla, A.K., Dwivedi, B.S., Singh, V.K. and Gill, M.S. (2009). Role of Macro and Micronutrients. Indian J. Fert.; 5(5): 11-12, 15-18, 21-24 \& 27-30.

Singh, V.K. and Tripathi, V.K. (2010). Efficacy of $\mathrm{GA}_{3}$, boric acid and zinc sulphate on growth, flowering, yield and quality of strawberry cv. Chandler. Progressive Agriculture, 10(2): 345-348.

Suvalaxmi, Palei, Arun Kumar Das, Ajit Kumar Sahoo, Dilip Kumar Dash and Saudamini Swain (2016). Influence of plant growth regulators on strawberry (Fragaria $\times$ ananassa) cv. chandler under Odisha condition. International Journal of Recent Scientific Research, 7(4): 9945-9948.

Vishal, V.C., Thippesha, D., Chethana, K., Maheshgowda, B.M., Veeresha, B.G. and Basavraj, A.K. (2016). Effect of various growth regulators on vegetative parameters of strawberry Cv. Sujatha. Research Journal of Chemical and Environmental Sciences, 4(4): 68-71

Yadav, I., Jitendra Singh, Bharat Meena, Pravin Singh, Sanjay Meena, Shraddha Neware and D.K. Patidar (2017). Strawberry Yield and Yield Attributes after Application of Plant Growth Regulators and Micronutrients on Cv. Winter Dawn. Chem. Sci. Rev. Lett., 6(21), 589-59.

\section{How to cite this article:}

Mahendra Bairwa, V. M. Prasad and Vijay Bahadur. 2020. Effect of Plant Growth Regulators and Micronutrients on Vegetative Growth and Fruit Yield of Strawberry (Fragaria X Ananassa Duch.) cv. Chandler. Int.J.Curr.Microbiol.App.Sci. 9(09): 2647-2653.

doi: https://doi.org/10.20546/ijcmas.2020.909.330 